\title{
¿QUÉ FUE LA NUEVA ESPAÑA?
}

Luis del Castillo Múzquiz*

RESUMEN: A cinco siglos del encuentro entre dos mundos, que dio inicio a un periodo histórico en el cual se gestaron los cimientos del México actual, se analizan varios aspectos del proceso de creación y consolidación de Nueva España, su papel dentro de la monarquía hispánica y la Iglesia católica, así como sus posibles consecuencias en el desarrollo de la cultura mexicana.

$$
\text { শ্ৰ }
$$

\section{WHAT WAS NEW SPAIN?}

ABSTRACT: Five centuries after the encounter between two worlds, which began a historical period in which the foundations of today's Mexico were developed, several aspects of the process of creation and consolidation of New Spain, its role within the Hispanic monarchy and the Catholic church are analyzed, as well as its possible consequences in the flourishing of Mexican culture.

* Departamento Académico de Estudios Generales, ITAM. Para la realización de este trabajo conté con la valiosa colaboración de Sergio Ruiz de la Concha Obregón como asistente de investigación, para la recopilación y síntesis de información. Asimismo, quiero manifestar mi agradecimiento al Dr. Carlos J. McCadden, jefe de Departamento Académico de Estudios Generales, quien desde un principio brindó todo su apoyo para llevar a cabo el proyecto; así como también al Dr. Víctor Alberto Villavicencio Navarro, quien se mostró siempre dispuesto a cooperar conmigo para llevar a cabo el cometido; y al Dr. Raúl Figueroa Esquer, quien siempre me dio ánimos en esa tarea, revisó escrupulosamente el texto y me hizo importantes sugerencias. Por último, debo mi reconocimiento a la Mtra. María de Lourdes Ibarra Herrerías, por su atenta lectura de la última versión y sus sabias puntualizaciones. 
Se prohíbe su reproducción total o parcial por cualquier medio, incluido electrónico, sin permiso previo y por escrito de los editores.

PALABRAS ClAVE: Carrera de Indias, México colonial, monarquía católica, monarquía hispánica, Nueva España, religión en México.

Key words: Carrera de Indias, Catholic monarchy, colonial Mexico, Hispanic monarchy, New Spain, religion in Mexico.

Recepción: 19 de septiembre de 2019.

APROBACIÓN: 11 de noviembre de 2019.

DoI: $10.5347 / 01856383.0131 .000297165$ 


\section{¿QUÉ FUE \\ LA NUEVA ESPAÑA?}

\section{Introducción}

\section{Hace cinco siglos, a principios de 1519 ,} llegó a las costas de la península de Yucatán un grupo de expedicionarios europeos comandados por un hidalgo extremeño, quien pasó a la historia con el nombre de Hernán Cortés. Esta expedición no fue la primera ni la última, pero su excepcionalidad estriba en sus resultados; pues, a diferencia de otras, esta dio nacimiento a una entidad territorial llamada "Nueva España", la cual constituye uno de los antecedentes más importantes del México de hoy. Por ello, esa fecha es en sí misma un gran hito en la historia de nuestro país.

Quinientos años después, los mexicanos del siglo XXI nos encontramos frente a distintos desafíos internos y externos. Respecto a los primeros, muchos de los problemas que hoy enfrentamos, como la creciente desigualdad, tienen su origen en el pasado prehispánico y en la época colonial, y es importante conocerlos y comprenderlos cabalmente. Por otra parte, ante un mundo globalizado, cada vez más competitivo, tenemos que ofrecer a nosotros mismos y al resto de las naciones algo que sea atractivo. Una opción puede ser la cultura mexicana, que es producto de nuestra historia. ${ }^{1}$

${ }^{1}$ En 1996, como alternativa a los retos que México enfrentaba en ese momento y los que se veían venir, fue lanzada una propuesta interesante respecto al papel de nuestro país en el ámbito internacional: "Hacia afuera, la cultura mexicana ha sido, y sin duda seguirá siendo 
Fue durante los tres siglos del periodo novohispano, es decir, desde principios del siglo XVI hasta el 27 de septiembre de 1821, fecha en que se consumó la Independencia, cuando tuvo lugar el complejísimo proceso de gestación de México y, por ende, de la cultura mexicana. Se trató de un choque y a la vez de una fusión de pueblos y culturas americanos, europeos y, hay que señalarlo también, africanos y asiáticos. A lo largo del texto explicaré el proceso de invención de Nueva España y cómo llegó a convertirse en un virreinato; también expondré su papel en el contexto internacional y particularmente dentro de la monarquía hispánica, además de la forma en que se fue configurando su población.

\title{
La invención de Nueva España
}

\author{
En una nao que de esta Nueva España de \\ Vuestra Sacra Majestad despaché a diez y seis días \\ de julio del año de [mil] quinientos y diez y nueve, \\ envié a Vuestra Alteza muy larga y particular relación \\ de las cosas hasta aquella sazón, después que \\ yo a ella vine, en ella sucedidas... ${ }^{2}$
}

El texto del epígrafe corresponde a la primera línea de la segunda carta de relación, enviada el 30 de octubre de 1520 por Hernán Cortés a su rey Carlos I de Castilla y Aragón y V de Sacro Imperio Romano-Germánico. Se trata de la primera vez en la historia que es mencionado el nombre de

nuestra mejor carta de presentación, y quizás la única que tengamos que sea realmente nuestra y realmente una carta. La literatura y la cocina mexicana, la arquitectura y los sitios arqueológicos, las iglesias y la artesanía, la pintura, los colores y sabores de todos los pueblos de México son lo que honestamente puede identificarnos afuera, y enorgullecernos ante cualquier embate, cualquier crítica cualquier atisbo de escepticismo. Es nuestra verdadera ventaja comparativa, no el petróleo o el sol, ni las naranjas o jitomates del TLC, ni los talentos cosmopolitas de nuestros funcionarios. En épocas donde naciones como Francia e Italia enfatizan su diferencia a través de su pasado y su manufactura cultural, México, cuyos esplendores culturales no le piden absolutamente nada a los países citados, debiera dedicarle la misma importancia, los mismos recursos, la misma voluntad política a esta tarea. Nuestra vocación en el mundo, y en México, es la cultura." Esa propuesta fue parte de una conferencia dictada por Jorge G. Castañeda, en el marco del ciclo "Los compromisos con la nación", celebrado en el Polyforum Cultural Siqueiros en abril de 1996. Jorge G. Castañeda, "El dilema migratorio", en The Estados Unidos Affair. Cinco ensayos sobre un "amor" oblicuo, 1996, México, Aguilar, p. 31.

${ }^{2}$ Hernán Cortés, "Segunda carta relación”, en Cartas de relación, 19a. ed., 2002, México, Porrúa, p. 37. 
Nueva España. Fue, por lo tanto, el propio Cortés quien lo ideó para el territorio que esperaba conquistar. Para esa fecha, el ambicioso capitán ya había sido expulsado, junto con sus hombres, de México-Tenochtitlan y se preparaba para el asedio a esa ciudad, que comenzó siete meses después, el 30 de mayo de 1521, y concluyó el 13 de agosto de ese año. ${ }^{3}$

Esto significa que, en realidad, Nueva España surgió como una entelequia, una expectativa en la mente del hidalgo extremeño, quien tras haber estudiado las circunstancias políticas del territorio mesoamericano, quiso fundar un gran reino, que con su mismo nombre daba gloria no solamente a su rey, sino también a un proyecto de expansión castellana con mucho tiempo de existencia y que se estaba materializando en la figura del joven monarca. Ninguno de los otros topónimos con los que otros conquistadores rebautizaron posteriormente a territorios americanos alcanza tales pretensiones. Baste recordar algunos: Nueva Galicia, Nueva Vizcaya, Nueva Castilla, Nueva Andalucía, Nueva Toledo.

Este constructo sería oficializado por el propio soberano Carlos de Habsburgo, el 15 de octubre de 1522, una vez que hubo recibido la segunda carta de relación, mediante una Real Cédula en la que daba a Cortés nombramiento de gobernador, capitán general y justicia mayor de la Nueva España. ${ }^{4}$ Con ese documento, el monarca validaba la

${ }^{3}$ Hernán Cortés, “Tercera carta relación”, en ibid., p. 205. Cabe advertir al lector que un autor ya se ha referido a Cortés, en una biografía sobre este famoso personaje, como "inventor de México". Sin embargo, a lo largo de la obra no desarrolló o justificó esa idea. Juan Miralles, Hernán Cortés. Inventor de México, 5a. ed., 2004, Barcelona, Tusquets. Tiempo después, el antropólogo, arqueólogo e historiador francés Christian Duverger, especialista en el Postclásico mesoamericano, publicó un libro intitulado Cortés. La biografía más reveladora, 2005, Madrid, Taurus. En este texto, Duverger hace la interesante propuesta de que el conquistador fue el creador de un México mestizo, incluso con la idea de que fuese independiente de la Corona castellana. Ahora bien, pienso que el conquistador no fue exactamente el creador de México y mucho menos de un reino independiente de Castilla; pero sí que lo fue, precisamente, del reino de Nueva España, y cierto es que procuró, desde el principio, atraer población española al virreinato que efectivamente constituyó la génesis del México actual.

4 “"[V]os, el dicho Hernando Cortés, tengáis o pretendáis tener por el descubrimiento e conquista de la dicha tierra seáis nuestro gobernador e capitán general de toda la tierra e provincias de la dicha Nueva España e de la dicha cibdad de Temistitlán, e que hayáis tengáis la nuestra justicia cevil e militar en las cibdades, villas e lugares que al presente están en ellas, pobladas de aquí en adelante, ansí de los naturales de la dicha tierra, como de los cristianos españoles que en ella están e de aquí en adelante a ellas fueren en los oficios de alcaldías e 
creación de un nuevo reino en América. El hidalgo de Medellín se convirtió así en la máxima autoridad militar y administrativa, pero además, el joven emperador delegaba en él la principal función de un rey, es decir, la impartición de justicia. Ahora había que consolidar este gran logro.

Desde antes de la emisión de ese documento, Hernán Cortés, pese a los consejos de algunos de sus allegados, ya había mandado hacer la traza de la capital del nuevo reino, justo sobre las ruinas de la ciudad vencida, la cual tuvo su propio ayuntamiento desde diciembre de 1522, aunque comenzó a funcionar tiempo más tarde. Efectivamente, como señaló Bernardo García Martínez, fue sobre el señorío de México-Tenochtitlan y su "aura imperial", su dominio tributario (y en algunos casos político), su prestigio (y ahora derrota) militar, que el conquistador sentó las bases de la nueva entidad, ${ }^{5}$ que heredó de los castellanos de la Reconquista y de los mexicas del Postclásico un fuerte deseo de expansión, así como la idea de imperio.

En este sentido, cabría preguntarnos qué extensión tenía en esos primeros años Nueva España. La respuesta no es fácil. En la Real Cédula que otorga a Cortés los nombramientos de gobernador, capitán general y justicia mayor, se lee lo siguiente: "las tierras e provincias de Aculuacán ${ }^{6}$ e San Juan de Ulúa, llamada la Nueva España, donde está la gran laguna en que está edificada la gran ciudad de Temistitlán-México"7; es decir, el territorio comprendido desde la cuenca de México hasta la costa veracruzana. Sin embargo, el nuevo reino creció pronto por las acciones del conquistador para someter a más indígenas y apropiarse

alguacilazgos e otros oficios de justicia que en ellas hobiese." Documento 25, Real Cédula de nombramiento de Hernán Cortés como gobernador y capitán general de la Nueva España e instrucciones para su gobierno. Valladolid, 15 de octubre de 1522, en José Luis Martínez (comp.), Documentos cortesianos, vol. I (1518-1528, secciones I a III), 1993, México, FCE-UNAM, pp. 250-253. Miralles, op. cit., pp. 383-384; José Luis Martínez, Hernán Cortés: versión abreviada, 1992, México, FCE, pp. 235-237.

${ }^{5}$ La primera acta formal del cabildo de la ciudad de México está fechada el 8 de marzo de 1524. Martínez, Hernán Cortés, pp. 247-251; Bernardo García Martínez, "Los años de la Conquista”, en Nueva historia general de México, 2010, México, El Colegio de México, pp. 176-179.

${ }^{6}$ Probablemente se refería al territorio ubicado entre el altepetl de Culhuacán, al sur de México-Tenochtitlan.

${ }^{7}$ Véase el documento 25 "Real Cédula de nombramiento de Hernán Cortés como gobernador y capitán general de la Nueva España e instrucciones para su gobierno. Valladolid, 15 de octubre de 1522”, en José Luis Martínez (comp.), Documentos cortesianos, vol. I (1518-1528, secciones I a III), 1990, México, FCE-UNAM, pp. 250-253. 
de sus tierras. García Martínez escribe que si en 1521 la ciudad conquistadora (respecto al resto de los atepemeh mesoamericanos) ahora era conquistada, poco después, ya convertida en la ciudad de México española, pasaría nuevamente a ser conquistadora. ${ }^{8}$ Hernán Cortés logró someter rápidamente al dominio castellano (en algunos casos mediante alianzas políticas y en otros utilizando la fuerza) no solo la región que controlaba la Triple Alianza formada por México-Tenochtitlan, Texcoco y Tlacopan, sino también otros territorios mesoamericanos como Michoacán y Tlaxcala.

La base territorial sobre la cual se edificó Nueva España fue sobre todo mesoamericana. Hacia mediados del siglo XVI, los españoles lograron dominar parte de la zona maya, lo cual no habían podido hacer los mexicas; sin embargo, muchas áreas de la región no fueron sometidas sino hasta las siguientes dos centurias. ${ }^{9}$ No obstante, las expediciones de los aventureros castellanos continuaron hacia Norteamérica en busca de reinos y tesoros maravillosos o del estrecho que comunicara el océano Atlántico con el Pacífico, como el famoso caso de Álvar Núñez Cabeza de Vaca. En parte, ese es el origen del reino vecino de Nueva Galicia, fundada por Nuño Beltrán de Guzmán. ${ }^{10}$

Poco más tarde, en la década de 1540, el descubrimiento de yacimientos de minerales preciosos en el actual estado de Zacatecas propició la fundación de la ciudad que hasta la fecha lleva ese nombre y fomentó también el avance español hacia tierras de Aridamérica. Pero esa expansión fue mucho más lenta y difícil, en gran medida por el tipo de población indígena, muy distinta de Mesoamérica. Se trata, pues, de un proceso que duraría más de un siglo.

${ }^{8}$ García Martínez, op. cit., pp. 177 y 179.

${ }^{9}$ Durante los siglos XVI y XVII, de las zonas dominadas por los españoles huyeron mayas que se refugiaron en la selva y establecieron ahí nuevos asentamientos vinculados a señoríos todavía no conquistados. Tal es el caso, por ejemplo, de los lacandones. No obstante, toda la zona sufrió un fuerte proceso de aculturación por la presencia española. Véase la obra de María Julia Sierra Moncayo y Reynaldo Sordo Cedeño, Atlas histórico de México, México, ITAM, 2017, especialmente los mapas "Territorios dominados por la Triple Alianza" y "Conquistas españolas. 1519-1555", en las pp. 33 y 77; Laura Caso Barrera, "Vidas fugitivas: los pueblos mayas de huidos en Yucatán", en Pilar Gonzalbo Aizpuru (dir.), Historia de la vida cotidiana en México, vol. I, "Mesoamérica y los ámbitos indígenas de la Nueva España”, 2004, México, El Colegio de México-FCE, pp. 473-499.

${ }^{10}$ Luis Weckmann, La herencia medieval de México, 1996, México, El Colegio de MéxicoFCE, pp. 59-72. 


\section{La consolidación de Nueva España}

...y haciendo uso de la plenitud de la potestad apostólica y con la autoridad de Dios omnipotente [...] y como Vicario de Jesucristo, [...] os donamos concedemos y asignamos perpetuamente, a vosotros y a vuestros herederos y sucesores en los reinos de Castilla y León, todas y cada una de las islas y tierras predichas $y$ desconocidas que hasta el momento han sido halladas por vuestros enviados y las que se encontrasen en el futuro... ${ }^{\prime \prime}$

Hacia 1519, cuando Hernán Cortés llegó con sus expedicionarios a las costas de la actual República Mexicana, los castellanos ya habían llevado a cabo la conquista y el poblamiento de las Antillas Mayores (La Española, Cuba, Jamaica y Puerto Rico), archipiélago que sirvió de base para continuar los planes de expansión hispana en todo el Nuevo Mundo no descubierto aún por ellos. Ese proceso implicó una estrecha colaboración entre los monarcas y sus vasallos. Si bien desde el primer viaje de Cristóbal Colón la reina Isabel la Católica esperaba poder financiar la empresa, se vio en la necesidad de aceptar inversionistas privados. Más tarde, la Corona castellana tendría participación económica en otras expediciones, pero para la segunda década del siglo XVI esa práctica fue abandonada, principalmente por falta de capital. En adelante, los distintos capitanes expedicionarios tendrían que gastar dinero de su propio peculio para sufragar todos los gastos. ${ }^{12}$

No obstante, los actos de toma de posesión de las tierras que se iban ocupando en América se hacían en nombre de los reyes de Castilla y León. Las palabras del papa Alejandro VI en las bulas Inter Coetera, a pocos meses del primer hallazgo de Cristóbal Colón, dejaban claro que los reyes

${ }^{11}$ Alejandro VI, Bula Inter Coetera, 3 de mayo de 1493, en Joseph Metzler (comp.), America Pontificia. Primi saeculi evangelizationis, 1493-1592, 1991, Ciudad del Vaticano, Editriche Vaticana, vol. I, pp. 72-75.

${ }^{12}$ Ya había habido expediciones hacia la zona del Darién y hacia la costa atlántica de la actual Colombia; sin embargo, aún no se lograba establecer poblaciones fijas ahí. Miralles, op. cit., pp. 21-24; Antonio-Miguel Bernal, La financiación de la Carrera de Indias (1492-1824), 1992, Sevilla-Madrid, Fundación El Monte, pp. 100-101. Para el caso particular de Nueva España, véase Silvio A. Zavala, Los intereses particulares en la conquista de la Nueva España, 1933, Madrid, Imprenta Helénica. 
de Castilla eran los señores naturales del Nuevo Mundo, y esa concesión apostólica no podía ser puesta en duda ni usurpada por ninguno de sus súbditos. A ellos les quedaba claro que su lugar era el de simples agentes de sus soberanos y, en dado caso, dependían de ellos para obtener las recompensas que creían merecer por sus hazañas. ${ }^{13}$

Así pues, si bien Hernán Cortés fue, sin lugar a dudas, el inventor de Nueva España, no era su dueño, y tanto él como sus hombres lo sabían. La Corona castellana pronto se encargó de hacerse presente en el nuevo reino a través de funcionarios. El 15 de octubre de 1522, el mismo día que el emperador Carlos V, como rey de Castilla, nombró a Cortés gobernador, capitán general y justicia mayor de Nueva España, le envío también instrucciones para el buen gobierno del nuevo reino y le avisó del nombramiento de cuatro funcionarios reales, encargados de cuidar la Real Hacienda y vigilar al conquistador. En el documento se lee lo siguiente: "Y para lo que toca al recaudo de nuestra hacienda, y porque haya con vos personas cuerdas e oficiales nuestros, [...] a los cuales vos encargo miréis e tratéis bien como a criados e oficiales nuestros, e les deis parte de todo lo que os pareciere que conviene a nuestro servicio, e que por razón de sus oficios la deben haber, de manera que ellos usen y ejerzan, y puedan usar y ejercer como conviene". ${ }^{14}$

${ }^{13}$ Baste como ejemplo el pregón por parte de Vasco Núñez de Balboa, en la toma de posesión del Mar del Sur (océano Pacífico): "Vivan los muy altos e muy poderosos reyes don Fernando e doña Juana, reyes de Castilla e de León e de Aragón, etc., en cuyo nombre e por la Corona real de Castilla tomo e aprehendo la posesión real e corporal e actualmente destas mares e tierras e costas e puertos e islas australes, con todos sus anejos e reinos e provincias que les pertenecen o pertenecer pueden, en cualquier manera e por cualquier razón e título que sea o ser pueda, antiguo o moderno, e del tiempo pasado e presente o por venir, sin contradicción alguna. E si alguno otro príncipe o capitán, cristiano o infiel, o de cualquier ley o secta o condición que se, pretende algún derecho a estas tierras e mares, yo estoy presto e aparejado de se lo contradecir e defender en nombre de los reyes de Castilla, presentes o por venir, cuyo es aqueste imperio e señorío de aquestas Indias, islas e Tierra-Firme septentrional e austral..." Gonzalo Fernández de Oviedo y Valdés, Historia general y natural de las Indias, islas y tierra firme del mar Océano, Madrid, Real Academia de la Historia, 1853, t. II, de la 2a. parte, 3a. de la obra, capítulo III, p. 13; véanse las dos bulas Inter Coetera de Alejandro VI, 3 de mayo de 1493 y 4 de mayo de 1493, en Metzler, op. cit., pp. 72-75 y 79-83.

${ }^{14}$ Documento 26, "Carta de Carlos V a Hernán Cortés en que le da instrucciones para el gobierno de Nueva España y le anuncia el envío de oficiales reales", Valladolid, 15 de octubre de 1522, en Martínez, Documentos cortesianos, pp. 254-256. 
En realidad, estos nombramientos no constituían ninguna novedad en la forma en que la Corona castellana controlaba a sus vasallos en las Indias. Se trataba, pues, de un sistema de pesos y contrapesos que se había implantado ya en las Antillas, todavía en vida de Cristóbal Colón. Los monarcas españoles (de los Reyes Católicos en adelante) y sus principales colaboradores procuraron que ninguno de sus súbditos en América tuviera demasiado protagonismo.

El gobierno de Cortés tuvo poca duración. Probablemente los oficiales reales llegaron a Ciudad de México hacia inicios de 1524. Desde un principio comenzaron las rivalidades entre ellos mismos y la hostilidad hacia el conquistador. Algunos lo acusaron de excederse en la autoridad que le había sido otorgada por el monarca, a tal grado que podía representar un peligro para los intereses del emperador. Pero fue el hidalgo extremeño quien precipitó su propia destitución. Se ausentó de la capital novohispana casi dos años, de octubre de 1524 a junio de 1526, en una malhadada expedición a la Hibueras (actual Honduras); y durante ese tiempo su teniente de gobernador y los funcionarios reales protagonizaron una vergonzosa rebatiña por el poder en la que se dejaba ver su gran ambición y sus pocas ganas de servir a su rey. ${ }^{15}$

A la vuelta del conquistador todo pareció volver a la normalidad, pero el daño ya estaba hecho. Escandalizados el emperador y sus colaboradores por la conducta de Cortés y de los oficiales, fue enviado otro agente de la Corona, Luis Ponce de León, con instrucciones de destituirlo de los cargos con que había sido premiado e iniciarle un juicio de residencia. ${ }^{16}$ El proceso se retrasó, puesto que Ponce de León falleció a los pocos días de haber llegado a México, en julio de 1526, y lo sucedió en el gobierno del nuevo reino otro funcionario llamado Marcos de Aguilar, quien a su muerte fue relevado en funciones por otros hombres comisionados para ello por su monarca, hasta diciembre de $1528 .^{17}$

${ }^{15}$ Martínez, Hernán Cortés, pp. 259-310.

${ }^{16}$ El juicio de residencia era una suerte de auditoría que se hacía a los funcionarios de la Corona una vez que ya no ejercían el cargo que les había sido otorgado. Durante dos meses, los residentes del lugar podían levantar acusaciones contra el funcionario. Era uno de los procedimientos mediante los cuales los reyes castellanos mantenían el poder en América. Ibid., pp. 310-313.

${ }^{17}$ Ibid., pp. 310-319. 
Hernán Cortés, el inventor de Nueva España, nunca más volvió a gobernarla, pero su creación sobreviviría durante tres siglos. El 9 de diciembre de 1528 tomaron posesión en México los miembros de una Real Audiencia que el rey había mandado instaurar en la capital novohispana, la segunda en territorio americano después de la de Santo Domingo. A causa de la corrupción de sus integrantes, empezando por su presidente, Nuño Beltrán de Guzmán, hubo que suprimirla y destituir a sus miembros. Fue creada una segunda Audiencia por Cédula Real en julio de 1530 , la cual entró en funciones al año siguiente ${ }^{18}$ y persistió hasta la consumación de la Independencia. Mediante estas acciones el monarca se hacía más presente en el recién creado reino. Pero conviene detenernos un poco en las implicaciones del establecimiento de esta institución.

La figura de la Real Audiencia tiene su origen en la Castilla del siglo XIV. Se trataba de un órgano colegiado que ayudaba al rey a cumplir su principal función: la impartición de justicia. Durante el siglo siguiente adquirió independencia, de tal manera que podía sesionar sin la presencia del monarca. La primera se estableció definitivamente en Valladolid, cuando la corte del rey era todavía itinerante, y fue dotada del sello real que validaba lo determinado por los oidores, es decir, los ministros que la componían. Ello hacía que fuera Real Audiencia, Corte y Chancillería. Esto significaba que sus resoluciones valían exactamente igual que si el propio soberano lo hubiese mandado. A finales del siglo XV, ciertos oidores llegaron a definir su institución como el "cuerpo místico del rey". ${ }^{19}$ En otras palabras, se trataba de un desdoblamiento del propio monarca en esa institución.

El segundo tribunal de este tipo establecido en la Corona castellana se ubicó en Ciudad Real y después en Granada. Durante los siglos XV y XVI surgieron otras Reales Audiencias, pero en Castilla solamente esas

${ }^{18}$ Francisco Miguel Martín Blázquez, "Los últimos altos magistrados de la Real Audiencia de México y sus reacciones ante la coyuntura histórica de la independencia (1808-1824)", tesis de doctorado en Humanidades y Ciencias Sociales, 2017, Madrid, Universidad Francisco de Vitoria, pp. 123-128; Tomás Polanco Alcántara, Las reales audiencias en las provincias americanas de España, 1992, Madrid, Mapfre, pp. 35-38.

${ }^{19}$ Bartolomé Clavero, "La monarquía, el derecho y la justicia”, en Enrique Martínez Ruiz y Magdalena de Pazzis Pi (coords.), Las jurisdicciones, 1996, Madrid, Actas, pp. 15-38. 
dos tuvieron el sello real; o sea, fueron las únicas que podían llamarse Real Audiencia, Corte y Chancillería. Sin embargo, es de advertir que tanto la de Santo Domingo como la de México sí tenían ese estatus, al igual que el resto de las que se fundaron subsecuentemente en territorio hispanoamericano. ${ }^{20}$

Los magistrados de las Reales Audiencias, Cortes y Chancillerías debían impartir justicia a nombre del rey, conforme a derecho, y particularmente basándose en el ius commune, el derecho que era general a toda la cristiandad. Por ello, debían contar con "razón y sabiduría", mediante una sólida formación adquirida gracias a los estudios generales o universidades de esa época. Para realizar sus funciones era menester que tuvieran conocimientos de derecho civil, de origen principalmente romano, así como también de derecho canónico. Además, debían estar versados en las especificidades del derecho castellano. Por otra parte, este cuerpo debía contar con un presidente, nombrado por el rey. Se procuraba que sus miembros no tuviesen intereses particulares en el territorio jurisdiccional de la Audiencia, lo cual implicaba que fueran oriundos de otro sitio. ${ }^{21}$ Sin embargo, en América, a medida que fue transcurriendo el tiempo, hubo varios magistrados naturales del lugar donde residía la Audiencia.

Al establecer la Real Audiencia de México, Carlos I se había hecho todavía más presente en Nueva España. Con ello desaparecía el peligro de que Cortés o algún otro aventurero pretendiese detentar el poder absoluto en el nuevo reino. No obstante, poco después el emperador y sus colaboradores consideraron necesario que el monarca tuviera otro representante más en Nueva España, el virrey.

Se trataba de una figura creada durante el siglo XV por los monarcas aragoneses ante la imposibilidad de estar en todos los territorios que formaban su Corona, que se extendía por el Mediterráneo, ante lo cual los reyes nombraban familiares o miembros de la alta nobleza para que los representaran. Este recurso se hizo todavía más necesario durante el reinado de los Reyes Católicos, pues Fernando vivía en Castilla

${ }^{20}$ Ibid.; Polanco Alcántara, op. cit., pp. 167-168.

${ }^{21}$ Clavero, op. cit. 
con su esposa, y en 1503 adquirió el reino de Nápoles. Empero, en el caso de Castilla, con las Capitulaciones de Santa Fe de 1492 los monarcas otorgaron a Cristóbal Colón el nombramiento de virrey, con lo cual dieron nacimiento al Virreinato de las Indias. El almirante fue destituido, aunque tiempo después fue rehabilitado en su hijo Diego Colón. Sin embargo, una vez fallecido este, no se autorizó la sucesión en su hijo y fue declarado desaparecido en el año de 1535, mismo año en que se creó el de Nueva España, con capital en Ciudad de México. ${ }^{22}$

Conviene ahora detenernos a reflexionar acerca del establecimiento de la Real Audiencia de México y el Virreinato de Nueva España, que sustituía al de la familia Colón en Santo Domingo. ¿Qué papel estaba adquiriendo el reino creado por Hernán Cortés? Si bien Santo Domingo había sido la capital de las Indias durante el periodo antillano, la llegada de los españoles a las costas mesoamericanas debe haber producido en ellos alguna sorpresa. Hasta la expedición de Hernández de Córdoba, los conquistadores castellanos no habían visto construcciones sólidas como las que encontraron en la península de Yucatán, y no imaginaban una ciudad con el grado de urbanización de la capital mexica. Vemos el testimonio de Bernal Díaz del Castillo sobre la vista del mercado de Tlatelolco, desde su templo mayor:

Y después de bien mirado y considerado todo lo que habíamos visto, tornamos a ver la gran plaza y la multitud de gente que en ella había unos comprando y otros vendiendo, que solamente el rumor y zumbido de las voces y palabras que allí había sonaba más que de una legua, y entre nosotros hubo soldados que habían estado en muchas partes del mundo, y en Constantinopla, y en toda Italia y Roma, y dijeron que plaza tan bien compasada y con tanto concierto y tamaña y llena de tanta gente no la habían visto. ${ }^{23}$

${ }^{22}$ Manuel Rivero Rodríguez, La edad de oro de los virreyes. El virreinato en la monarquía hispánica durante los siglos XVI y XVII, 2011, Madrid, Akal, pp. 40-51, 59-64; Miralles, op. cit., pp. 17-43; José Ignacio Rubio Mañé, El virreinato, vol. I, "Orígenes y jurisdicciones, y dinámica social de los virreyes, 2a. ed., 1983, México, FCE, pp. 13-22.

${ }^{23}$ Bernal Díaz del Castillo, Historia verdadera de la conquista de la Nueva España, 1962 , México, Porrúa, pp. 160-161. Para tener más testimonios sobre la impresión que causó en el soldado la capital mexica, véase el capítulo XCII, en las pp. 158-164. 
Por otra parte, las sociedades que encontraron en Mesoamérica eran mucho más complejas que las que habían conocido en el mar Caribe. Si bien es imposible calcular la población que había ese momento en el área mesoamericana, se sabe que no tenía parangón respecto a la de las Antillas. En otras palabras, por el tipo de población y por todas las riquezas materiales que habían encontrado los conquistadores, Nueva España era el mayor éxito económico de la aventura castellana en América. Pero regresemos ahora al momento en que se convirtió en un virreinato.

\section{EI Virreinato de Nueva España}

Y comenzando por lo más importante, digo que la mayor seguridad y fuerza que tienen estas tierras es el virrey que la gobierna y la Real Audiencia; y lo que más puede sustentar esta fuerza es que sustentes ellos entre si mucha conformidad y paz.

VIRREY MARTÍN ENRÍQUEZ ${ }^{24}$

La existencia de un virrey implicaba que esa persona representaba al propio monarca. Algunos autores se han referido a esa figura como el alter ego del rey. Sin embargo, hay que tener cuidado con esta afirmación. Efectivamente, el virrey solía tener el cargo de gobernador, capitán y justicia mayor, como lo fue Hernán Cortés, pero también desempeñaba la presidencia de la Real Audiencia de México. ${ }^{25}$ Por lo tanto, no debemos olvidarnos de que ese organismo constituía en sí mismo otra representación, aunque colectiva, del rey.

El primer virrey de Nueva España fue Antonio de Mendoza. Si bien él mismo no era poseedor de ningún título nobiliario, pertenecía a la aristocrática familia Hurtado de Mendoza, parte de la Grandeza de España. Además, era hombre con experiencia militar, como correspondía a su condición. Tal fue el perfil de los virreyes el resto del siglo XVI

24 “Instrucción y advertimientos que el virrey don Martín Enríquez dejó al conde de Coruña (don Lorenzo Suárez de Mendoza), su sucesor en los cargos de Nueva España”, 25 de septiembre de 1580, en Anselmo de la Portilla (comp.), Instrucciones que los virreyes de Nueva España dejaron a sus sucesores, 1873, México, Imprenta de Ignacio Escalante, t. I, pp. 53-78.

${ }^{25}$ Rubio Mañé, op. cit., pp. 23-29. 
y durante el siglo siguiente: hombres pertenecientes a la más alta nobleza castellana, dignos de representar a su soberano.

La figura del virrey como mecanismo de control por parte de la Corona castellana estaba también muy limitada. A lo largo de todo el periodo virreinal surgieron distintos conflictos de competencia entre los virreyes y los oidores de la Audiencia de México que ellos mismos presidían. Por si fuera poco, al desaparecer el Virreinato de Indias, dentro de la jurisdicción del de Nueva España estaba también la Audiencia de Santo Domingo, en la isla de La Española, y con el transcurrir del tiempo se fueron creando otras, en principio sujetas a los virreyes novohispanos: en 1542 se fundó la llamada "de los Confines", con sede en Santiago de Guatemala; en 1548 se creó la de Nueva Galicia, con sede en Guadalajara, y en 1583 se fundó otra en Manila, en las islas Filipinas, conquistadas por los españoles décadas atrás. Cada una comprendía varias gobernaciones y capitanías generales, gobiernos locales, alcaldías mayores y corregimientos. ${ }^{26}$ Esta situación era resultado del expansionismo castellano en territorio americano y, en este último caso, asiático. De ahí que tengamos que hacia finales del siglo XVI haya que hacer una distinción entre el reino de Nueva España, que prácticamente abarcaba el territorio que comprendió desde la época cortesiana, y el Virreinato de Nueva España, que era algo mucho más complejo, sobre todo, porque si bien varias Reales Audiencias estaban sujetas a él, el grado de sujeción no era el mismo. Además, nunca se tuvo en la Corte real en Madrid una idea clara de los territorios americanos y su división política, y surgían a menudo conflictos por la jurisdicción de las distintas zonas. ${ }^{27}$

Básicamente, la principal diferencia en cuanto a la sujeción hacia el Virreinato de Nueva España estribaba en el grado de dependencia económica. Esta era mayor en el caso de la de Santo Domingo y la de Filipinas, pues podían mantenerse en gran medida gracias al envío de remesas de dinero llamadas “situados". Yucatán, por su parte, necesitaba también ayuda monetaria para su defensa contra ataques extranjeros, y además estaba dentro de la jurisdicción de Audiencia de México; no obstante,

${ }^{26}$ Ibid., pp. 28-41.

${ }^{27}$ Ibid., p. 41. 
gozaba de autonomía para diversos asuntos de gobierno, y las dificultades de comunicación por tierra, hasta bien entrado el siglo XX, hacían que estuviese poco ligada a la antigua Tenochtitlan. ${ }^{28}$ En el caso de la Audiencia de Guadalajara, si bien su jurisdicción comprendía todo el reino de Nueva Galicia, el de Nueva Vizcaya, el de Nuevo León, es decir, prácticamente toda la parte septentrional que se fue expandiendo a lo largo de tres siglos, también había muchos intereses económicos que los ligaban a la capital novohispana. En cambio, la Audiencia de los Confines, después llamada de Guatemala, comprendía prácticamente todo el territorio centroamericano, incluida la región de Chiapas y el Soconusco, y no tenía tantos vínculos con Ciudad de México.

Durante la segunda mitad del siglo XVIII, la Real Ordenanza de Intendentes, promulgada en 1786, supondrá una reconfiguración del territorio del Virreinato novohispano, pero las distintas Reales Audiencias no desaparecieron. Los efectos de todo ello se verían una vez que tuvo lugar la separación respecto a España en el siglo XIX. No es de extrañar, entonces, que algunos de los territorios del virreinato amenazaran en ocasiones con separarse y otros lo hicieran definitivamente. Sin embargo, todos formaban parte de algo más complejo: una monarquía compuesta.

${ }^{28}$ Agradezco a Carlos Conover Blancas la información proporcionada acerca del área circuncaribeña. Para profundizar en los situados, véanse los trabajos contenidos en Carlos Marichal y Johana von Grafenstein (coords.), El secreto del imperio español: los situados coloniales en el siglo XVIII, 2013, México, El Colegio de México-Instituto de Investigaciones Dr. José María Luis Mora; específicamente sobre la cuestión de Yucatán, véanse los trabajos de Sergio Quezada y Elda Moreno Acevedo, "Del déficit a la insolvencia. Finanzas y Real Hacienda en Yucatán, 1760-1816", Mexican Studies/Estudios Mexicanos, 21/2 (2005), p. 316; Verónica Cordero González, El movimiento mercantil del puerto de Campeche en la época del comercio libre y neutral, 2004, Campeche, Consejo Nacional para la Cultura y las Artes-Instituto Nacional de Antropología e Historia-Centro INAH Campeche, pp. 51-83; Peter Gerhard, La frontera sureste de la Nueva España, 1991, México, UNAM-Instituto de Investigaciones Históricas, trad. de Stella Mastrangelo, pp. 47-48; respecto a la Audiencia de México y su jurisdicción durante las últimas décadas del siglo XVII y las primeras del XVIII, igualmente agradezco a Víctor Saúl Bonilla Meza sus aclaraciones, así como facilitarme el borrador de su tesis de licenciatura en Historia, "Gobernar en la incertidumbre: la Audiencia de México entre 1680 y 1715", que será defendida en 2020, en México, UNAM, Facultad de Filosofía y Letras, Colegio de Historia. 


\title{
Nueva España como parte de la monarquía católica
}

\author{
Y no obsta que todos estos reinos se hallen unidos, \\ y constituyan oy una como Monarquía, por donde \\ parece, que importa poco, que todos los vasallos de \\ ellos se igualen, o por mejor decir, que no se pueden \\ tener por extranjeros ni peregrinos los que están \\ debajo del dominio de un mesmo rey. \\ JUAN DE SOLÓRZANO PEREYRA ${ }^{29}$
}

El texto del epígrafe corresponde a un intento, por parte del jurista madrileño Juan de Solórzano Pereyra (1575-1655), de explicar las complejidades del Imperio español, del cual era súbdito. Pero últimamente sus trabajos han sido retomados para entender otras realidades de la época. En la última década del siglo XX, el historiador británico John H. Elliott publicó un novedoso artículo en el cual postula que los estados nacionales de la edad contemporánea surgieron a partir de distintos conglomerados de pequeños estados, cuyos habitantes eran súbditos de un mismo monarca, conjuntos a los cuales llamó "monarquías compuestas". 30

Si bien el intelectual inglés se enfocaba en las repercusiones de ese fenómeno en Europa, el texto atañe también a la América hispana y, por ende, al Virreinato de Nueva España. Estos territorios pertenecían al que posiblemente haya sido en su momento el más complejo de esos conglomerados de estados: la monarquía hispánica, llamada también monarquía católica, por el título que ostentaban sus soberanos desde los Reyes Católicos en adelante: Su Majestad Católica.

Como bien es sabido, el azar hizo que cayeran varias coronas en la cabeza de Carlos de Habsburgo. ${ }^{31}$ Aunque no se trataba de ninguna

${ }^{29}$ Juan de Solórzano Pereyra, Política indiana, 1739, Madrid, Imprenta de Gabriel Ramírez, t. II, lib. IV, cap. XIX, §37, p. 169.

${ }^{30}$ John H. Elliott, “A Europe of composite monarchies”, Past \& Present, 137 (1992), pp. 48-71.

${ }^{31}$ La Corona de Castilla, que incluía, además de los reinos musulmanes conquistados por los reyes castellanos a lo largo de la Reconquista, el emirato conquistado de Granada, las islas Canarias y los territorios del Nuevo Mundo; la de Aragón, con sus cuatro reinos peninsulares, al que se añadía el de Navarra y los italianos de Nápoles, Sicilia y Cerdeña; el Círculo Borgoñón, es decir, los Estados vinculados al Ducado de Borgoña: Países Bajos, Luxemburgo y el Franco Condado (antiguamente Condado de Borgoña); y los Estados patrimoniales de los Habsburgo: Austria, Carintia, Carniola y Tirol. Por si fuera poco, el mismo año en que Cortés 
unidad política, este soberano tenía la pretensión de que tanto él como sus descendientes fuesen titulares de una "monarquía universal", probablemente a partir del impulso expansionista castellano. Sin embargo, es por todos conocido que poco antes de morir, al ver frustrados sus planes, abdicó a favor de su hijo Felipe II la soberanía de aquellos territorios donde tenía más poder efectivo: las Coronas de Castilla (con sus "Indias") y Aragón, el Círculo Borgoñón, así como el ducado de Milán. Todo esto se convertiría en la monarquía católica.

Se trata, pues, efectivamente de una monarquía compuesta, que estaba constituida, a la vez, por monarquías compuestas. Recuérdese que Felipe II se convirtió también en 1580 en rey de Portugal, con sus posesiones en África, América y Asia. ¿Qué papel cumplían Nueva España y el resto de los territorios americanos en medio de este galimatías? Tomás Pérez Vejo, a partir del estudio de representaciones pictóricas de las principales ciudades del Nuevo Mundo, sostiene que sus habitantes las concebían como "repúblicas urbanas", es decir, como entes políticos autónomos, que formaban parte de una "confederación" sobre la cual reinaba Su Majestad Católica. ${ }^{32}$ No obstante, en la práctica, los diferentes reinos o estados de la monarquía hispánica, así como sus ciudades, villas y pueblos tenían distintos derechos y privilegios dentro de todo ese complejo entramado.

En el siglo XVII, Juan de Solórzano Pereyra expuso que los territorios de la monarquía católica podían dividirse en dos grupos, de acuerdo con el tipo de unión que mantenían con el soberano: unas eran las "uniones aeque principaliter" (que podríamos traducir como igualmente importantes), en las cuales los estados mantenían sus propias leyes, fueros y privilegios; es decir, todas sus tradiciones y sus instituciones, y el rey debía gobernar cada una de modo particular, como si solo fuera

llegó a las costas de lo que después sería Nueva España, Carlos de Habsburgo obtuvo el nombramiento de emperador del Sacro Imperio Romano Germánico, y más tarde conquistaría el ducado de Milán. A todo ello se le suele llamar en la historiografía "Imperio de Carlos V."

${ }^{32}$ Esos términos de "república urbana" y de "confederación" son utilizados por el autor para explicarnos la concepción, en el imaginario colectivo de esas sociedades, el papel de dichas ciudades americanas de la monarquía hispánica, pero es importante precisar que no los utilizaban en aquella época de esa manera. Sin embargo, resulta muy útil tener todo esto en cuenta para entender la actitud de los distintos ayuntamientos de este Nuevo Mundo, a partir de los acontecimientos de 1808. Tomás Pérez Vejo, Repúblicas urbanas en una monarquía imperial, 2018, Bogotá, Crítica-Universidad Nacional de Colombia. Instituto de Estudios Urbanos. 
señor de ese estado. Este era el caso de todos los estados que constituían la Corona de Aragón, dentro y fuera de la Península Ibérica, así como los correspondientes al Círculo Borgoñón, también el ducado de Milán y en su momento la Corona de Portugal. En otra situación se encontraban las "uniones accesorias". Se trataba de reinos o provincias que, anexados a otro, eran considerados jurídicamente como parte de él, de tal forma que sus habitantes tenían los mismos derechos y obligaciones ante el monarca. Justamente, explicaba el propio Solórzano Pereyra, ese era el caso de "las Indias" de Castilla, es decir, sus territorios en América. ${ }^{33}$

En otras palabras, todos los reinos que componían el Virreinato de Nueva España eran "uniones accesorias" de Castilla. Eran vistas como una extensión y, por lo tanto, tenían que adoptar todas las instituciones castellanas. Esto implicaba que, aunque el rey estuviese representado —en las Reales Audiencias y en los virreyes_- los asuntos más importantes se manejaban desde la Corte de Madrid, por medio del Consejo de Indias.

Este organismo tenía su origen en el Consejo Real castellano, en el que solía reunirse un grupo de colaboradores del rey. Desde el reinado de los Reyes Católicos hubo que crear distintos cuerpos de este tipo, a

33 “Que en virtud desta unión, o incorporación, aun se pudiera, y puede fundar y pretender que el Imperio de las Indias, y por el consiguiente Consejo que las gobierna, es parte del de Castilla, y ha de gozar de sus mismas preeminencias y antigüedad; en especial habiéndose hecho, como se hizo esta unión accesoriamente. De que resulta, que las Indias se gobiernan por las leyes, derechos y fueros de Castilla, y se juzgan y tienen por una misma Corona. Lo cual no sucede así en los reinos de Aragón, Nápoles, Sicilia y Portugal y Estados de Milán, Flandes y otros que se unieron y agregaron, quedándose en el ser que tenían, o como los doctores dicen: AEQUE PRINCIPALITER; porque en tal caso, cada uno se juzga por diverso, y conserva sus leyes y privilegios." Juan de Solórzano Pereyra, "Memorial y discurso de las razones que se ofrecen para que el Real y Supremo Consejo de las Indias deba preceder en todos los actos públicos al que llaman de Flandres (1629)", en Obras varias posthumas del doctor..., 1776, Madrid, Imprenta Real de la Gazeta, pp. 188-189; véase también del mismo autor, Política Indiana, t. II, lib. IV, cap. XIX, §§ 36-37, p. 169; y Elliott, op. cit., pp. 52-53; es importante recordar que Juan de Solórzano Pereyra comenzó una recopilación de las leyes referentes al mundo indiano, que continuaría Antonio de León Pinelo. El proyecto no se materializó sino hasta 1680, cuando fue publicada la obra Recopilación de leyes de los reinos de las Indias; al respecto, véase Rafael Altamira, "El primer proyecto de recopilación de Indias, hecho por D. Juan De Solórzano Pereyra”, Bulletin Hispanique, 42/2 (1940), pp. 97-122; para profundizar en la situación de los territorios americanos desde el punto de vista de la historia del derecho, véase Francisco de Icaza Dufour, Plus ultra. La monarquía católica en Indias 1492-1898, 2016, México, Porrúa-Escuela Libre de Derecho. 
fin de atender las necesidades de los monarcas. Cuando subió al trono su nieto Carlos de Habsburgo, se vio en la necesidad de dividir el Consejo de Castilla y creó, en 1519, una sección dedicada exclusivamente a los dominios en América, que hacia 1524 se convirtió en una institución aparte. Actuaba en nombre del rey y otorgaba nombramientos para cargos importantes, además de que expedía reales cédulas y reales órdenes para resolver los problemas generales que se presentaban en las Indias. Era un órgano legislativo, administrativo y último tribunal ante el cual se podía apelar una sentencia dictada en América. Sin embargo, al igual que ocurría con las Reales Audiencias, el monarca tenía siempre la última palabra. Cabe decir también que a medida que esa entelequia que fueron las Indias aumentaba de tamaño — respecto al territorio dominado - y, por lo tanto, de importancia, también aumentaban los funcionarios reales del Consejo de Indias y adquiría más relevancia.

Ahora bien, el Consejo de Indias tuvo otro antecedente cuyas competencias fueron más específicas: la Casa de Contratación establecida en Sevilla en 1503, cuya existencia se prolongó hasta 1790. Se trata de una institución cuya principal función era, en principio, como su nombre lo indica, regular los "tratos y contratos", es decir, el comercio entre la Corona castellana y sus posesiones en América, lo que se llamó la Carrera de Indias.

\title{
Nueva España en la Carrera de Indias
}

\author{
Y aunque no es hasta el siglo XVIII cuando los españoles \\ llaman, sin eufemismo, colonias a sus territorios de \\ América, a semejanza de lo que holandeses, ingleses \\ $y$ franceses hicieran con las suyas, de lo que no hay \\ lugar a dudas es que, desde el primer momento, \\ como negocio colonial fue concebido \\ $y$ organizado el tráfico indiano.
}

ANTONIO-MiguEL BERNAL ${ }^{34}$

Efectivamente, como afirma Antonio-Miguel Bernal, desde que Cristóbal Colón realizó su primera expedición en 1492, uno de los temas discutidos con los Reyes Católicos fue el comercio con las Indias. Recordemos que

\footnotetext{
${ }^{34}$ Antonio-Miguel Bernal, op. cit., p. 100.
} 
el proyecto colombino tuvo lugar en un contexto de expansión atlántica, iniciada desde principios del siglo XV por dos Coronas ibéricas, Portugal y Castilla, las cuales habían entrado en pugna por la conquista de las islas Canarias.

Portugal había hecho bastantes adelantos en la exploración de la costa occidental africana. La expansión castellana y portuguesa sobre América y Asia tuvo lugar en un momento en que los adelantos tecnológicos en la navegación impulsaron la exploración de nuevos territorios por parte de distintos pueblos. La hazaña de Colón sirvió como un acelerador para la creación de lo que hoy llaman algunos autores una "primera era global". ${ }^{35}$

El tráfico de mercancías y de hombres desde la Península Ibérica hacia el Nuevo Mundo comenzó con el primer viaje de Cristóbal Colón, en 1492. Poco después, en 1495, una ordenanza "concedió a todos los súbditos de Castilla la facultad de ir a América para establecerse, explotar o ejercer el comercio". ${ }^{36}$ Para regular ese trasiego se creó en 1503 la Casa de Contratación, con sede en Sevilla, que tenía su propia Real Audiencia (aunque no fue chancillería). No solamente se hacía cargo de cuestiones mercantiles, sino que en un principio se encargó de todo lo referente a las tierras recién descubiertas, hasta que se constituyó el Consejo de Indias. Hasta finales del siglo XVIII, la Casa fue la encargada de otorgar las licencias para pasar al Nuevo Mundo. Más tarde se formó también el Consulado de Cargadores a Indias, que fungió como tribunal mercantil de primera instancia para dirimir los pleitos entre los comerciantes transatlánticos y funcionaba a la vez como gremio de mercaderes ante la Corona. ${ }^{37}$

A la ruta marítima entre la Península Ibérica y las posesiones en América, así como al tráfico de mercancías y de hombres, se le ha llamado Carrera de Indias. La Carrera funcionaba a partir del monopolio de

${ }^{35}$ David Alonso García, Mercados y mercaderes en los siglos XVI y XVII, 2016, Madrid, Síntesis, pp. 9-17.

${ }^{36}$ Clarence H. Haring, Comercio y navegación entre España y las Indias en la época de los Habsburgos, 1939, México, FCE, trad. de Emma Salinas, p. 5.

${ }^{37}$ Conviene recordar que, a partir de 1717, la Casa de Contratación y el Consulado de Cargadores a Indias se trasladaron a Cádiz. Manuel Bustos Rodríguez, El Consulado de cargadores a Indias en el siglo XVIII (1700-1830), 2017, Cádiz, Universidad de Cádiz, pp. 17-22. 
algunos puertos. El único desde el que se podía tener comunicación con el Nuevo Mundo desde Europa era Sevilla, de ahí que fuese la sede de la Casa de Contratación. A partir de 1543 se estableció, además, que el tránsito debía de hacerse por medio de flotas, es decir, convoyes de barcos que viajaban juntos para prevenir ataques de potencias enemigas o de piratas y corsarios. Los navíos debían zarpar desde el puerto hispalense, surcar las aguas del río Guadalquivir hasta llegar al océano Atlántico y dirigirse a las islas Canarias. Ahí hacían la primera escala antes de llegar a la isla de la Española, desde la cual algunos se desviaban a distintos puntos de las Antillas, para dirigirse a su destino final. En el continente solamente hubo dos puertos habilitados para tener comunicación con la metrópoli: Veracruz, para Nueva España, y Nombre de Dios (y después Portobelo) en el istmo de Panamá, para conectarse con el Cono Sur. Algunos navíos podían llegar también a Cartagena de Indias, dado que esa zona quedaba muy aislada del Virreinato del Perú. ${ }^{38}$

Los galeones que se dirigían al istmo de Panamá realizaban ahí mismo una feria con las mercancías cargadas, a la cual acudían los grandes comerciantes de Lima, la capital peruana. En el caso de Nueva España, las condiciones climatológicas y de salubridad de Veracruz obligaban a que las ferias de las flotas se realizaran en Ciudad de México, situación que prevaleció hasta el siglo XVIII, cuando comenzaron a realizarse en Xalapa. No obstante, Nueva España tenía un lugar especial en esa Carrera de Indias.

Cuando Cristóbal Colón y sus hombres zarparon de Puerto de Palos en 1492, se pretendía con ese viaje trazar una nueva ruta marítima a la zona de la especiería, es decir, las islas Molucas. Pese a haber topado con un continente cuya existencia se desconocía, la Corona castellana no renunció al proyecto original. Así pues, de forma paralela a la conquista de Hernán Cortés del territorio que después se convertiría en Nueva España, la famosa expedición de Fernando de Magallanes, tras pasar del océano Atlántico al Pacífico a través del estrecho que lleva su nombre, llegó a las islas Filipinas. Sin embargo, los intentos caste-

${ }^{38}$ Sergio M. Rodríguez Lorenzo, La Carrera de Indias (la ruta, los hombres, las mercancías), 2015, Santander, La Huerta Grande-Robinson Librería Náutica, pp. 13-32. 
llanos de conquista y poblamiento de Asia no se concretaron sino hasta décadas después. La existencia de Nueva España sería un factor determinante para la presencia castellana en el Extremo Oriente, pues a finales de 1564 zarpó de las costas del actual Jalisco una expedición a cargo de Miguel López de Legazpi. Al año siguiente, uno de sus más experimentados miembros, Andrés de Urdaneta, encontró una corriente marítima que facilitaba el tornaviaje a la parte septentrional del continente americano, y tras ciento treinta días de navegación, el 8 de octubre de 1565 arribó a la bahía de Acapulco. ${ }^{39}$

A partir de entonces, un galeón proveniente de Filipinas realizó una travesía con mercaderes españoles residentes en Manila. Se llegaba a Acapulco, único puerto americano con el que podían comerciar los habitantes de Filipinas, en el cual se realizaba una feria a la que acudían mercaderes de Ciudad de México y más tarde también de Lima. De esa manera, Nueva España funcionó como puente entre la metrópoli y sus posesiones en el continente asiático. Además, también hubo comercio entre el reino de Nueva España y otros territorios de la monarquía hispánica en América, tales como el reino de Guatemala, y el mismo Virreinato del Perú, aunque estuvo suspendido este último por espacio de aproximadamente un siglo, hasta que fue rehabilitado en el siglo XVIII.

Nueva España tuvo una posición geográfica estratégica en la monarquía hispánica. Además, los principales mercaderes del Virreinato, quienes operaban desde la capital, tuvieron otra fuente de abastecimiento de productos, además de Veracruz, lo cual les dio una situación ventajosa y el control del comercio novohispano. Todo esto, aunado a una serie de circunstancias políticas, económicas y sociales tanto en Europa como en diversas regiones del Virreinato, provocó que durante siglo y medio algunos grupos, como los mercaderes, gozaran de una relativa autonomía, que más tarde se vería amenazada por los reyes Borbones. $^{40}$

${ }^{39}$ Carmen Yuste López, Emporios transpacificos. Comerciantes mexicanos en Manila 1710-1815, 2007, México, UNAM-Instituto de Investigaciones Históricas, pp. 21-41.

${ }^{40}$ Carmen Yuste postula que el comercio transpacífico significó para la monarquía hispánica "una alternativa intercolonial". Loc. cit. Sobre la relativa autonomía novohispana, véase, de la misma autora, "Autonomía novohispana y reformismo borbón", en Carmen Yuste (coord.), La diversidad del siglo XVIII novohispano, 2000, México, UNAM-Instituto de Investigaciones 
En todos estos casos de comercio transatlántico o transpacífico, los compradores eran principalmente peninsulares y criollos que habitaban Hispanoamérica. Los residentes en la Península Ibérica y Manila que viajaban a América esperaban adquirir materias primas, pero el principal objetivo eran los metales preciosos que producían las minas del Perú y de Nueva España. En los siglos XVI y XVII Perú envió más minerales a Europa, de ahí que haya tenido durante esa época mayor importancia económica. Para el siglo siguiente la situación había cambiado y Nueva España era la principal productora de plata.

\section{Los pobladores españoles}

Como a mí me convenga buscar toda la buena orden que sea posible para que estas tierras se pueblen, y los españoles pobladores y los naturales de ellas se conserven y perpetúen, y nuestra santa fe en todo se arraigue

HERNÁN CORTÉS ${ }^{41}$

En 1524, Hernán Cortés quería que Nueva España estuviese habitada no solamente por la población autóctona, sino que llegasen más españoles. Esto demuestra que concebía al nuevo reino de la monarquía como una entidad en la que necesariamente debían residir también familias castellanas. Su idea era que Nueva España tuviese un poblamiento definitivo y que fuese una colonia de Castilla, en el sentido en que se entendía en la época. ${ }^{42}$ Por ello, antes de partir a su fatídica expedición

Históricas, pp. 147-162. Sobre el comercio entre las distintas regiones hispanoamericanas, véase Matilde Souto Mantecón, "El renacimiento de la historia del comercio colonial: estudios de caso y visiones comparativas", en Virginia Guedea y Leonor Ludlow (coords.), El historiador frente a la historia. Historia económica en México, 2003, México, UNAM-Instituto de Investigaciones Históricas, pp. 35-45.

${ }^{41}$ Hernán Cortés, "Cuarta carta de relación”, México, 15 de octubre de 1524, en Cartas de relación, p. 259.

42 "COLONIA, es puebla o término de tierra que se ha poblado de gente extranjera, sacada de la ciudad, que es señora de aquel territorio, o llevada de otra parte. También se llamaban colonias las que pobladas de sus antiguos moradores les había el pueblo romano dado los privilegios de tales. [...] En España hubo muchos pueblos que fueron colonias de romanos." Sebastián de Covarrubias, Tesoro de la lengua castellana o española, 1611, Madrid, Luis Sánchez, 
a las Hibueras dictó ordenanzas de poblamiento. Más tarde, al dar cuentas al emperador Carlos V, advierte que "de algunas de ellas los españoles que en estas partes residen no están muy satisfechos, en especial de aquellas que los obligan a arraigarse en la tierra; porque todos, o los más, tienen pensamientos de se haber con estas tierras como se ha habido con las islas que antes se poblaron [las Antillas mayores], que es esquilmarlas y destruirlas, y después dejarlas". ${ }^{43}$

Así pues, Cortés estaba interesado en que los españoles que estaban con él permanecieran y se asentaran definitivamente en Nueva España y no buscaran solo el enriquecimiento rápido para volver a su tierra. Por eso añadía, "y porque me parece que sería muy gran culpa a los que de lo pasado tenemos experiencia, no remediar lo presente y por venir, proveyendo en aquellas cosas por donde nos es notorio haberse perdido las dichas islas, mayormente siendo esta tierra [...] de tanta grandeza y nobleza, y donde tanto Dios Nuestro Señor puede ser servido y las reales rentas de vuestra majestad acrecentadas suplico a vuestra majestad las mande mirar". ${ }^{4}$

En estas últimas líneas Cortés alude a los problemas que se habían presentado en las Antillas, en las que la población aborigen fue exterminada y dejó de haber mano de obra barata o gratuita para los españoles, debido a su codicia desmedida y su falta de apego al lugar. Cortés obli-

p. 448. Consultado en $<$ ntlle.rae.es $>$. Respecto a la idea de poblamiento definitivo, véase Martínez, Hernán Cortés, p. 270. Ricardo Levene (Las Indias no eran colonias, 1951, Madrid, Espasa-Calpe) sostiene desde un punto de vista estrictamente jurídico que los territorios españoles en América no eran considerados "colonias" en la legislación indiana de los siglos XVI y XVII, e incluso ni siquiera en la del XVIII. No obstante, en las leyes promulgadas en esos tres siglos sí utilizaba el término "Indias", de manera genérica, para referirse a las posesiones en América y Asia, las cuales eran, en estricto sentido, uniones accesorias de Castilla, es decir, no se trataba tampoco de reinos autónomos. Por otro lado, si confrontamos esas aseveraciones con la historiografía de los distintos territorios de la monarquía católica en el Nuevo Mundo, podemos observar que en la práctica sí funcionaron como colonias, tanto en la forma como se fueron poblando de españoles (aunque no se les llamase "colonos", sino "pobladores"), como en la relación económica que tenían con su metrópoli (exportadoras de materias primas y compradoras de bienes cuya producción tenían prohibida). Además, sí existen obras del siglo XVIII en la que algunos autores se refieren al Nuevo Mundo como "nuestras colonias". Véase, por ejemplo, la obra de Antonio de Capmany y de Monpalau, Apéndice a las costumbres maritimas del libro del Consulado, 1791, Madrid, Imprenta de Sancha, p. 223.

${ }^{43}$ Cortés, Cuarta carta de relación, pp. 259-260.

${ }^{44}$ Ibid., p. 260. 
gaba a sus subordinados que habían sido agraciados por él con encomiendas de indios, a permanecer un mínimo de ocho años en Nueva España, que los casados trajesen a sus esposas en un lapso de año y medio y los solteros contrajesen nupcias en el mismo plazo. Por su parte, él hizo lo mismo, como lo constata el hecho de la presencia y muerte de su primera esposa en Coyoacán ese año. Además, cuando emprendió la expedición a las Hibueras, se quedaron en Ciudad de México numerosos primos suyos que habían venido después de la caída de Tenochtitlan, como los hermanos Rodrigo y Pedro de Paz. Por si fuera poco, tras su viaje a España de 1528 a 1530, Cortés volvió a Nueva España con una comitiva de cuatrocientas personas, seguramente muchos de ellos parientes y paisanos extremeños, además de su propia madre y su nueva esposa. Cabe decir al respecto que desde 1524 uno de sus últimos actos como gobernador fue expedir un arancel que gravaba las mercancías que circulaban en el camino entre México y Veracruz, lo cual nos habla de la temprana inserción del nuevo reino en la Carrera de Indias, gracias a la existencia de compradores españoles. ${ }^{45}$

Aquellos que se quedaron en Nueva España recibieron también a otros familiares y vecinos de la Corona de Castilla, y así comenzó el flujo migratorio de españoles peninsulares hacia Nueva España, que continuó hasta bien entrado el siglo XX. Los recién llegados llamaban luego a otros deudos y paisanos, de tal manera que la corriente de migración siguió redes familiares y de paisanaje que en ocasiones estaban tendidas a lo largo del Virreinato y a ambos lados del Atlántico y a veces del Pacífico. Los pobladores, como se les llamó en su época, podían dedicarse a las más diversas actividades: sastres, zapateros, talabarteros, carpinteros, etc. Muchos llegaron también como cargadores, es decir, comerciantes de la Carrera de Indias, los cuales, al encontrar mejores oportunidades y al insertarse en una familia ya asentada, decidían quedarse.

De acuerdo con la reglamentación de la Casa de Contratación, solamente a los vasallos de la Corona de Castilla se les concedía licencia para pasar a Indias. Sin embargo, llegaron a internarse legalmente en

${ }^{45}$ Martínez, Hernán Cortés, pp. 264-266, 269-271, 303-307, 364-366. 
el Nuevo Mundo súbditos de la monarquía católica que no eran castellanos, como aragoneses, flamencos, napolitanos, etc. También se puede constatar la presencia en Nueva España de vecinos provenientes de Estados alemanes o del reino de Francia o de la República de Génova. No obstante, se trata de excepciones, y buscaron, tal como lo hacían en la Península Ibérica, insertarse en la sociedad local.

Si durante los siglos XVI y XVII la mayor parte de los inmigrantes peninsulares a Nueva España procedía de Andalucía y Extremadura, para el último siglo del virreinato la mayoría eran oriundos del norte de la Península Ibérica: navarros vascos, cántabros, asturianos y gallegos. En parte esto se debía a que la Casa de Contratación fue haciendo más estrictos los requisitos de las licencias para pasar a Indias, como demostrar "limpieza de sangre", es decir, no ser descendiente de judíos, musulmanes ni gitanos.

Aunque la población española siempre fue minoritaria en el territorio del Virreinato, en las ciudades y villas fundadas específicamente para españoles tuvieron mucha presencia. Por otra parte, fue inevitable la convivencia de los europeos con otros grupos, como los indígenas, los esclavos traídos de África para las labores más pesadas y algunos inmigrantes asiáticos, y hubo uniones, matrimoniales o ilegítimas, entre los distintos sectores de la población, lo que se conoce como mestizos y castas. De acuerdo con los libros parroquiales en los que se registraban los bautizos, hubo tres categorías jurídicas para los nacidos en Nueva España: españoles, indios y negros, mestizos y castas. La pertenencia a una implicaba distintos derechos y obligaciones. Con todo, no se trató de un sistema tan rígido como podría pensarse.

Un ejemplo es el caso documentado de Miguel Montero, barretero que trabajaba en el real minero de Santa Rosa de Cusihuiriachi. A veces se presentaba como "coyote natural de la ciudad de México", mientras que otros decían que era "indio natural de Tepeji”. ${ }^{46}$ Así, los vasallos novohispanos constituyeron una población sumamente heterogénea, con muchas diferencias culturales. Pero compartían todos un mismo soberano y la misma religión católica.

${ }^{46}$ Bernd Hausberger, "La vida en el noroeste. Misiones jesuitas, pueblos y reales de minas", en Gonzalbo Aizpuru (dir.), op. cit., vol. I, p. 447. 


\section{La Iglesia católica en Nueva España}

Era la Iglesia, y no la fuerza militar, la que conservaba la paz en la Nueva España, y la que unía a las diversas razas de la colonia en una sola grey de fieles.

DAVID BRADING ${ }^{47}$

A lo largo de tres siglos, la fe cristiana fue el principal punto de unión entre los habitantes del Virreinato novohispano. La incorporación de los indígenas a la Iglesia fue el principal factor de legitimización de la exploración y conquista de otros territorios y pueblos allende los mares. La evangelización del Nuevo Mundo fue, en gran medida, heredera de la guerra de Reconquista contra los musulmanes en la Península Ibérica, considerada en su época como una "guerra santa", ${ }^{48}$ aunque nunca se atrevieron los castellanos a llamarle así al proceso que tenía lugar en América.

A consecuencia de lo anterior, desde el reinado de los Reyes Católicos los monarcas ibéricos acumularon una serie de prerrogativas para el nombramiento de autoridades eclesiásticas y de recaudación y administración de bienes económicos en sus dominios en Europa y en América. A ello se le conoce como regio patronato, que en el caso americano llegó a llamársele regio vicariato, puesto que el soberano fungía como vicario del Papa en el Nuevo Mundo. Se trata sobre todo de un proceso que se dio desde finales del siglo XV hasta su culmen en el XVIII. Gracias a ello, los soberanos de la monarquía hispánica lograron tener gran poder sobre los clérigos, lo cual se acentuaba aún más en los territorios del Nuevo Mundo. ${ }^{49}$

${ }^{47}$ David. A. Brading, Mineros y comerciantes en el México borbónico (1763-1810), 1975, Madrid, FCE, trad. de Roberto Gómez Ciriza, p. 46.

${ }^{48}$ Ron Barkai, El enemigo en el espejo: cristianos y musulmanes en la España medieval, 1984, Madrid, Rialp, pp. 59 y ss.

${ }^{49}$ Ángel Fernández Collado resume el proceso con elocuentes palabras: "En 1486, Inocencio VIII otorgó la bula Ortodoxae fidei, por la que los Reyes Católicos obtuvieron el derecho de presentación o súplica de los candidatos a los obispados hispanos. En 1501, la bula Eximiae devotionis sinceritas de Alejandro VI, estableció el patronato universal sobre los reinos de Granada y Canarias, ampliado por Julio II para las Indias en 1508 con la bula Universalis ecclesia regiminis. El mismo año, este papa, con el breve Eximiae devotionis affectus otorgó a la Corona los diezmos de metales y piedras preciosas hallados en América y, en 1510, con la 
Así, desde los inicios de la expansión castellana en territorio americano hubo clérigos cuya principal función, además de proporcionar auxilio espiritual a los españoles, era evangelizar a los indígenas. La población que encontraron en Mesoamérica era muy distinta a la de las islas Antillas. Lo constataron pronto los conquistadores y, a partir de las primeras Cartas de relación de Cortés, se enteraron también el emperador y sus allegados. Así, el propio soberano escribió al inventor de Nueva España:

Y que principalmente tengáis grandísimo cuidado y vigilancia de que los indios naturales de esa tierra sean industriados e doctrinados, para que vengan en conocimiento de nuestra Santa Fe Católica, atrayéndolos para ello por todas las buenas mañas e buenos tratamientos que convenga, pues, a Dios Gracias, según vuestras Relaciones, tienen más habilidad y capacidad para que se haga en ellos fruto y se salven, que los indios de las otras partes que hasta agora se han visto, porque este es mi principal deseo e intención, y en ninguna cosa me podéis tanto servir..$^{50}$

En estas palabras del emperador vemos, por una parte, que el propio Cortés había percibido un grado de civilización más avanzado en los indígenas mesoamericanos, respecto de los que había conocido en

bula Romanus Pontifex concedió las tercias reales del resto de los diezmos. Unos años después, en 1518, el papa León X con la bula Sacro apostolatus ministerio permitió a la Monarquía dirigir la evangelización y establecer los límites de las diócesis americanas, labor que se canalizó a través de Consejo de Indias. En la Península [Ibérica], mediante la bula Eximiae devotionis affectus, de 1523, se extendió el derecho de presentación a todas las abadías y prelacías. Sería más tarde, en el siglo XVII, cuando las aspiraciones monárquicas, alejadas ya de la profunda conciencia católica de los inicios del Patronato, se verían colmadas. Los Borbones interpretaron el Patronato Regio como un derecho inherente a la soberanía y no como una gracia pontificia. El concordato de 1753 con Benedicto XIV constituyó una ratificación de dicho derecho y supuso la implantación del patronato universal en los reinos peninsulares, reservando al rey en nombramiento de todas las dignidades eclesiásticas, mayores y menores. Además, en 1762 , se impuso el pase regio o exequatur, que impedía publicar cualquier documento papal que no hubiera recibido el placet real." Historia de la Iglesia en España, 2007, Toledo, Instituto Teológico San Ildefonso, p. 35; María Teresa Álvarez Icaza Longoria, La secularización de doctrinas y misiones en el arzobispado de México 1749-1789, 2015, México, UNAM-Instituto de Investigaciones Históricas, pp. 23-30.

${ }^{50}$ Documento 26, "Carta de Carlos V a Hernán Cortés en que le da instrucciones para el gobierno de Nueva España y le anuncia el envío de oficiales reales", Valladolid, 15 de octubre de 1522. En Martínez (comp.), Documentos cortesianos, pp. 254-256. 
las Antillas, y al mismo tiempo, una profunda preocupación por parte del monarca en la conversión de sus súbditos recién adquiridos y los que se sumaran en el futuro. La empresa de la conquista del Nuevo Mundo iba a la par que la de su introducción a la Iglesia. ${ }^{51}$

No hay que perder de vista las inquietudes religiosas de los pensadores de la época. Desde la segunda mitad del siglo XII había surgido en la Europa cristiana una profunda preocupación por el Juicio Final, la salvación del alma y la actitud de clérigos y laicos ante la pobreza y la riqueza, así como qué tanto se apegaba a los preceptos del Evangelio. En ese contexto debemos comprender el surgimiento y auge de las órdenes mendicantes, la prerreforma católica en la Península Ibérica e incluso los movimientos reformistas del siglo XVI y la consecuente Contrarreforma, cuyo mayor logro fue el Concilio de Trento. Hay que hacer uso de la imaginación histórica y pensar en cómo influyó en las sociedades europeas, y particularmente las ibéricas, el hecho de haberse topado con el Nuevo Mundo. ${ }^{52}$

Luis Weckmann demostró que en el imaginario de los conquistadores estaban presentes reminiscencias de leyendas medievales: las amazonas, la isla mítica de California, las Siete Ciudades de Cíbola o El Dorado; al mismo tiempo, no dejaban de ser católicos. Además, en el pensamiento de algunos clérigos, sobre todo regulares, había ideas escatológicas acerca de una total evangelización de todo el orbe, previa al Juicio Final, cuando se cumplirían las promesas de Jesucristo, y que, por ende, la Divina Providencia había puesto frente a ellos un continente aún no explorado y sus habitantes, para que cumplieran su misión

${ }^{51}$ En este caso, el concepto de Iglesia no se limita a los clérigos, sino también a toda la comunidad de fieles que profesan la fe católica que, de acuerdo con la doctrina, constituye en sí misma el cuerpo místico de Jesucristo y tiene tres estados: la Iglesia Triunfante, compuesta por todos aquellos fieles difuntos que ya gozan de la gloria celestial; la Iglesia Purgante, constituida por los católicos cuyas almas se encuentran aún purgando los pecados capitales en el purgatorio; y la Iglesia Militante, que agrupa a todos los creyentes que se encuentran con vida.

${ }^{52}$ Elsa Cecilia Frost, La historia de Dios en las Indias. Visión franciscana del Nuevo Mundo, 2002, México, Tusquets, pp. 88 y ss.; de la misma autora "Toribio de Benavente, llamado Motolinía", en Juan A. Ortega y Medina y Rosa Camelo (coords.), Historiografía mexicana, vol. II, "La creación de una imagen propia. La tradición española", t. 2, 2012, México, UNAM-Instituto de Investigaciones Históricas, pp. 767-794; María de Lourdes Ibarra Herrerías, "Jerónimo de Mendieta"; y "Juan de Torquemada", en Ortega y Medina y Camelo, op. cit., vol. II, t. 2, pp. 795-826 y 827-851; Weckmann, op. cit., pp. 215-222. 
de ofrecer la salvación a millones de almas presas de una confusión provocada por el mismísimo Satanás. ${ }^{53}$ Para las fechas en que los castellanos llegaron al litoral de nuestro actual país, el propio Carlos de Habsburgo debe haber pensado de manera muy similar a los religiosos. Baste recordar sus esfuerzos para combatir el reformismo protestante en los territorios en que era soberano y su lucha contra el islámico Imperio Otomano.

Cuando los conquistadores lograban que los tlatoque ${ }^{54}$ indígenas se sometieran como vasallos al rey de Castilla y León, dicho acto incluía como requisito el bautismo. Desde el punto de vista de los europeos, los naturales de la tierra estaban recibiendo un sacramento mediante el cual se convertían en cristianos. Evidentemente, para los mesoamericanos la ceremonia implicaba solamente parte de los requisitos para la alianza con los hombres venidos del mar. ${ }^{55}$ No obstante, desde que los Reyes Católicos fueron agraciados por Alejandro VI con la bula Inter Coetera, de mayo de 1493, el pontífice los instó a promover la conversión de los indígenas de los territorios recién encontrados:

Os requerimos atentamente a que prosigáis de este modo esta expedición y que con el ánimo embargado de celo por la fe ortodoxa queráis y debáis persuadir al pueblo que habita en dichas islas a abrazar la profesión cristiana sin que os espanten en ningún tiempo ni los trabajos ni los peligros, con la firme esperanza y con la confianza de que Dios omnipotente acompañará felizmente vuestro intento. ${ }^{56}$

Ante este requerimiento del Papa, y a fin de llevarlo a cabo, tanto los Reyes Católicos como su nieto Carlos facilitaron que viajaran a América clérigos regulares, pertenecientes a órdenes mendicantes, expertos

${ }^{53}$ Frost, La historia de Dios, pp. 88 y ss., y "Toribio de Benavente”, pp. 767-794; Ibarra Herrerías, "Jerónimo de Mendieta", pp. 795-826, y "Juan de Torquemada", pp. 827-851; Weckmann, op. cit., pp. 48-58, 163-222. Julia Sierra Moncayo, retomando una idea de Luis Villoro, insistió en las distintas formas como se ha visto a los indígenas desde el siglo XVI hasta nuestros días. Julia Sierra Moncayo, "México antes de México", en Historia socio-politica de México, vol. I, 2018, México, ITAM-Departamento Académico de Estudios Generales, pp. 78-81; Joseph Pérez, Carlos V, 2004, Madrid, ABC, pp. 59-74.

${ }^{54}$ Es el plural de la voz nahua tlatoani.

${ }^{55}$ Pablo Escalante Gonzalbo y Antonio Rubial García, "Los pueblos, los conventos y la liturgia”, en Pilar Gonzalbo Aizpuru (dir.), op. cit., vol. I, pp. 377-379.

${ }^{56}$ Bula Inter Coetera, 3 de mayo de 1493. 
en la predicación de la religión católica, la evangelización y la educación. ${ }^{57}$ Eran los religiosos que se necesitaban para convertir a los autóctonos americanos en católicos. Entre ellos estaba también el célebre dominico Antón de Montesinos, cuyas acusaciones sobre los abusos de que eran víctimas los indígenas propiciaron la primera legislación relativa al tratamiento que debía darse a los naturales de las islas Antillas. No obstante, también se instauró en el archipiélago la institución de la encomienda, un mecanismo mediante el cual los indígenas debían pagar tributo en especie, además de prestar su fuerza de trabajo, a cambio de su adoctrinamiento en la fe cristiana. Como eran asignados a diferentes españoles, se le llamó también en sus inicios "repartimiento". ${ }^{8}$

En el caso de Nueva España, fue el propio Cortés quien instituyó la encomienda en Nueva España, a partir de su experiencia antillana, a fin de retener a la población española en el nuevo reino. Los beneficiarios fueron él mismo y el resto de los conquistadores, a los cuales les fueron repartidos indígenas en distinto número, de los cuales recibirían tributo y fuerza laboral. En el territorio mesoamericano, este proceso se facilitó al adaptar el sistema político prexistente. Así, cada señorío o altepetl se convirtió en una "doctrina" religiosa, para evangelizar a los vecinos,

${ }^{57}$ Los miembros del clero se dividen en dos ramas: el clero regular y el secular. El primero está compuesto por sacerdotes que viven en comunidad, dentro de una Orden religiosa (a veces llamadas entre los católicos 'religiones') y bajo una regla, como la de San Francisco de Asís, San Agustín de Hipona, Santo Domingo de Guzmán, San Ignacio de Loyola, San Benito, etc. En cambio, los miembros del clero secular (comúnmente llamados diocesanos) no están adscritos a ninguna de las Órdenes, ni se ven obligados a cumplir ninguna regla. Además, pueden poseer bienes materiales y la obediencia que deben a su superior no implica renuncia a la voluntad propia; no obstante, se encuentran dentro de una jerarquía de jurisdicción o sea, la jerarquía eclesiástica (Papa, cardenales, obispos, presbíteros, etc.). La principal función es realizar una labor pastoral, es decir, guiar a los laicos, a fin de que estos últimos lleven una vida acorde a las normas cristianas. De ahí el nombre de secular (saeculum o sea, siglo), porque viven en el mundo; en contraposición a los clérigos regulares que viven en el claustro, es decir, aislados de la sociedad. No obstante, los miembros de las Órdenes mendicantes tienen un estilo de vida mixto, en el que sí se sigue una regla (por ello son clérigos regulares, pero tienen también una vida activa, dentro de la cual sus principales actividades son la predicación, la evangelización y la educación. Por esto se recurrió a los regulares para incorporar a los indígenas americanos a la Iglesia católica. Empero, muchos de ellos ocuparon cargos dentro de la Jerarquía eclesiástica, ante la ausencia de seculares.

${ }^{58}$ El 27 de diciembre de 1512 Fernando el Católico sancionó las Leyes de Burgos o Reales ordenanzas dadas para el buen regimiento y tratamiento de los indios, adicionadas en Valladolid el siguiente año. Carmen Mena García, "Don Fernando el Católico o 'Señor de las Indias del Mar Océano'”, Revista de Indias, LXXVIII/272 (2018), pp. 33-38; Weckmann, op . cit., pp. 341-342. 
la cual se encomendaba a un conquistador (encomendero), quien se encargaría de velar por el bienestar espiritual de sus indios encomendados, con la ayuda de un religioso..$^{59}$

La presencia de clérigos comenzó con la llegada de Cortés, de tal suerte que él fue también promotor de la llamada "conquista espiritual". En un principio se contaban con los dedos de una mano, pero para 1524 había ya quince misioneros franciscanos en Nueva España. Aun así, el propio conquistador extremeño solicitó a su rey el envío de más frailes de la orden, así como de la de Santo Domingo, para catequizar a los naturales. Los primeros franciscanos del nuevo reino arribaron en 1526 y en 1533 llegaron los agustinos. Poco después comenzaron a llegar miembros de otras órdenes, como mercedarios, carmelitas, jesuitas. ${ }^{60}$

Durante el mismo siglo XVI arribaron también curas seculares, principalmente para atender las necesidades espirituales de la población española. Así se fue estableciendo en Nueva España la jerarquía eclesiástica, con sus respectivas parroquias y diócesis como la de Tlaxcala (1525-1526), México (1530), Antequera (1535), Michoacán (1536), etc. A algunos religiosos les fueron asignadas doctrinas indígenas; de igual manera, muchas órdenes de regulares llegaron a tener enorme influencia entre muchos españoles, y aunque predominaron los mendicantes, puesto que lo que más hacía falta eran evangelizadores activos, se puede constatar la presencia de una orden monacal, la de San Benito. Poco después se despertó una rivalidad entre los curas seculares y los religiosos regulares, que se acentuó al paso del tiempo. ${ }^{61}$

${ }^{59} \mathrm{La}$ encomienda era una concesión real distinta de las mercedes de tierra. Por otra parte, los repartimientos que se hicieron de indios encomendados en el siglo XVI no deben confundirse con el servicio por repartimiento, que sustituyó a la encomienda como forma de explotación a la población indígena. Weckmann, op. cit., pp. 341-343; Álvarez Icaza Longoria, op. cit., pp. 10-14; García Martínez, op. cit., pp. 179-185; Richard Konetzke, América latina, vol. II, 30a. ed., 2004, México, Siglo XXI, trad. de Pedro Scaron, pp. 160-176.

${ }^{60}$ García Martínez, op. cit., pp. 196-201; Antonio Rubial García, "Las órdenes mendicantes evangelizadoras en Nueva España y sus cambios”, en Pilar Martínez López-Cano (coord.), La Iglesia en Nueva España, 2010, México, UNAM-Instituto de Investigaciones Históricas, pp. 215-236; y La evangelización de Mesoamérica, 2002, México, Consejo Nacional para la Cultura y las Artes, pp. 5-8; Cortés, "Cuarta carta de relación”, pp. 257-258. Robert Ricard, La conquista espiritual de México. Ensayo sobre el apostolado y los métodos misioneros de las órdenes mendicantes en la Nueva España de 1523-1524 a 1572, 1947, México, Jus-Polis, trad. de Ángel María Garibay.

${ }^{61}$ Los religiosos de las órdenes monacales, a diferencia de los mendicantes, suelen dedicar su vida a la contemplación, alejados del mundo en sus monasterios. Una epidemia de la enfer- 
Fueron los propios religiosos regulares quienes insistieron en que los españoles estuviesen separados de los indígenas, a fin de que los últimos no se contaminaran con los malos ejemplos que podían ver en los europeos. A partir de las ideas providencialistas ya mencionadas, estos evangelizadores creían en la posibilidad de hacer de los indígenas cristianos ejemplares. Así, pues, se dividió a la población en dos sectores: la "república de españoles" y la "república de indios". ${ }^{62}$

\section{La Iglesia y la población autóctona de Nueva España}

Lo principal que siempre Su Majestad me ha mandado ha sido encargarme la cristiandad y buen tratamiento destos naturales; el medio por donde estas dos cosas yo he tratado han sido los religiosos, y desto me he ayudado para todo grandemente, y sin ellos puédese hacer poco.

VIRREY ANTONIO DE MENDOZA ${ }^{63}$

\section{Cada doctrina religiosa establecida en un altepetl o señorío sirvió para} erigir también una pequeña entidad política que se le conoció en su momento como "pueblo de indios" o "república de indios". En cada una

medad llamada por los indígenas cocoliztli dio lugar a que algunos devotos de la Virgen de Montserrat quisieran edificar un hospital y un santuario a esa advocación en la zona de Santa Fe, al poniente de la capital. Fue el origen del Curato de Montserrat de México, que se estableció en 1614 y duró hasta el 20 de enero de 1821, cuando el intendente de México ejecutó un decreto de las Cortes que sesionaban en Madrid y de su rey Fernando VII por el cual se suprimían las órdenes monásticas. Manuel Orozco y Berra, Apéndice al Diccionario universal de historia y de geografia, 1856, México, Imprenta de J. M. Andrade y F. Escalante, t. II (IX de la obra), pp. 863-870; García Martínez, op. cit., pp. 196-199, 213-214; Álvarez Icaza Longoria, op. cit., pp. 36 y ss.; véase también Sierra Moncayo y Sordo Cedeño, op. cit., pp. 84-85. Para profundizar, véase el caso de los padres jesuitas y su conflicto con Monseñor Juan de Palafox, en María de Lourdes Ibarra Herrerías, "El conflicto entre Juan de Palafox y la Compañía de Jesús", Estudios, 118 (2016), pp. 45-63.

${ }^{62}$ Entiéndase por "república" el significado de la época, es decir, comunidad. Sin embargo, en el caso de los indígenas podemos encontrar la palabra "república" en singular y en plural. En el primer caso se refiere a todos los indígenas de Nueva España; en el segundo, se hace alusión a los pueblos de indios. Frost, La historia de Dios, pp. 193-224 y "Toribio de Benavente...", pp. 767-794. Ibarra Herrerías, "Jerónimo de Mendieta...”, pp. 795-826 y “Juan de Torquemada...", pp. 827-851.

${ }^{63}$ Antonio de Mendoza, "Relación, apuntamientos y avisos que por mandado de S.M. di al Sr. D. Luis de Velasco, visorey, y gobernador y capitán general desta Nueva España”, en Anselmo de la Portilla (ed.), Instrucciones que los virreyes de Nueva España dejaron a sus sucesores. Añádense algunas que los mismos trajeron de la Corte y otros documentos semejantes a las instrucciones, 1873, México, Imprenta de Ignacio Escalante, t. I, pp. 9-49. 
de las principales localidades la población autóctona fue obligada a participar en la construcción de un convento, dirigido por un prior, para que fuera el centro religioso de la gente de ese pueblo y lugares aledaños. Además, en torno a esos edificios se hacía la nueva traza para congregar a los habitantes de esos núcleos indígenas, por lo que a veces se les llamaba también congregas o congregaciones. ${ }^{64}$

Esto no quiere decir que no hubiera continuidades respecto a la época prehispánica. No debemos olvidar la estrategia cortesiana de conquistar sin destruir. Si bien se trasladó a América la institución castellana del municipio, y los pueblos de indios con mayor población acabaron convirtiéndose en eso, la conversión de los señoríos prehispánicos en repúblicas de indios o doctrinas implicaba también una continuidad con los tiempos anteriores. Cada una de estas poblaciones tenía tres autoridades: una indígena, conocida durante el periodo colonial como "cacique", es decir, un tlatoani, elegido, al igual que los miembros del cabildo, entre los miembros de la nobleza local, con una duración de entre uno y dos años; otra española civil, que era el alcalde mayor o corregidor (dependiendo cada caso); y, por lo menos una española, pero religiosa, el doctrinero. En el caso de las poblaciones menores, sus habitantes estaban supeditados a la cabecera municipal para cuestiones civiles; para las religiosas, cada una era una "visita", que regularmente tenía una pequeña iglesia con una habitación para el clérigo que viajara desde el convento para atender las necesidades espirituales de sus habitantes. En ocasiones, sobre todo en las primeras décadas de la presencia española, a falta de un funcionario de la Corona castellana, los clérigos llegaron a impartir justicia a nombre del rey en algunas de las doctrinas. ${ }^{65}$ A medida que transcurrió el tiempo, fue desapareciendo la figura de los encomenderos.

Pero el papel de los clérigos no se limitó a la evangelización o a cubrir esa falta de autoridades civiles. La presencia de los religiosos

${ }^{64}$ Álvarez Icaza Longoria, op. cit., pp. 10-14; Escalante Gonzalbo y Rubial García, “Los pueblos, los conventos", pp. 367-390.

${ }^{65}$ Pablo Escalante Gonzalbo y Antonio Rubial García, "El ámbito civil, el orden y las personas", en Gonzalbo Aizpuru (dir.), op. cit., vol. I, pp. 413-441; Serge Gruzinski escribió una obra dedicada al proceso de occidentalización de los indígenas novohispanos, La colonización de lo imaginario. Sociedades indígenas y occidentalización en el México español. Siglos XVI-XVIII, 1991, México, FCE, trad. de Jorge Ferreiro Santana. 
entre los naturales fue crucial para el devenir de los grupos indígenas y su incorporación paulatina a la civilización occidental. Ellos introdujeron en las doctrinas novedades aparte de la fe católica. Los doctrineros realizaron obras como molinos, acueductos, canales hidráulicos y fuentes, construidas con tecnología moderna. Fueron también quienes trajeron a los antiguos altepemeh algunos productos agrícolas del Viejo Mundo, como duraznos, manzanos, higos, nueces, hortalizas, etc. Igualmente, enseñaron a los indígenas la crianza de animales como cerdos, ovejas, caballos. También les enseñaron a realizar oficios, como la fabricación de instrumentos musicales, de muebles, de textiles, calzado y otros. De igual manera, la vestimenta tradicional fue sustituida por otra que disminuía la desnudez de los indios. ${ }^{66}$

La presencia de los frailes también cambió muchos otros aspectos de la vida. Los indígenas tuvieron que asimilar una nueva religión. Los cronistas religiosos de la época relatan que los naturales acogían con entusiasmo a los evangelizadores y la fe cristiana. Para ellos, de momento, adoptar otro dios además de los que ya tenían no implicaba necesariamente una novedad. Además, el acto de bautizarse implicaba, para muchos, sellar una alianza con los españoles. No obstante, la labor de los evangelizadores fue ardua. Algunos sintieron una gran empatía con los autóctonos y los defendieron de los abusos de los conquistadores. Otros fueron más duros en su afán por cristianizar a los paganos. ${ }^{67}$

¿Cuánto tardaron los evangelizadores en lograr la conversión de todos los indígenas de Nueva España? Es imposible responder con precisión. Tenían que acabar no solamente con las creencias tradicionales, sino también con prácticas de la vida cotidiana, como por ejemplo, la poligamia entre los nobles. Los religiosos tuvieron que aplicar estrategias tales como enfocarse en adoctrinar a los niños, utilizar el teatro, establecer una liturgia y actividades paralitúrgicas que resultaran atractivas a los naturales, y también imponer castigos. ${ }^{68}$ Sabemos que han aparecido ídolos prehispánicos dentro de figuras cristianas. Además,

66 Pablo Escalante Gonzalbo y Antonio Rubial García, "La educación y el cambio tecnológico", en Gonzalbo Aizpuru (dir.), op. cit., vol. I, pp. 391-411.

${ }^{67}$ Escalante Gonzalbo y Rubial García, “Los pueblos, los conventos”..., pp. 377-379.

${ }^{68}$ Loc. cit. 
el culto a muchos dioses de la antigua religión fue sustituido por la adoración a santos cristianos, así como advocaciones de la Virgen María y de Jesucristo. El caso más conocido es el de la Virgen de Guadalupe, cuyo santuario (actual basílica y colegiata desde 1701) se encuentra en el mismo sitio en que era adorada la diosa Tonantzin. ${ }^{69} \mathrm{Al}$ terminar el siglo XVI, lo que había en el cerro del Tepeyac era ya un culto mariano, y para el siglo siguiente, pasó de ser mayoritariamente indígena a ser un punto de unión y motivo de orgullo de todos los sectores de población del Virreinato.

No podemos saber cuántos indígenas de la primera generación conquistada se convirtieron realmente; todavía para los hijos de ellos cabría la duda. Sin embargo, para la tercera generación ya eran cristianos. Eso no quiere decir que no se haya dado un sincretismo religioso todavía palpable hoy, en el siglo XXI. Sin embargo, por más reminiscencias que haya de formas de culto prehispánicas, se trata de prácticas cristianas.

Lo mismo podemos decir de la presencia de los clérigos en la expansión española hacia el septentrión del Virreinato durante los siglos XVII y XVIII. En las misiones del lejano norte, los religiosos tuvieron, al igual que sus antecesores en Mesoamérica, un papel central en el desarrollo de las comunidades. Ellos llevaban no solamente una nueva religión, sino también una nueva forma de vida a los indígenas, con una nueva moral. A veces, al igual que los evangelizadores que llegaron en el siglo XVI, tuvieron que tolerar una serie de prácticas que venían de un tiempo anterior, como las danzas o el consumo de bebidas alcohólicas en fiestas religiosas, comportamientos que a sus ojos eran indecentes. Pero se aseguraba un culto cristiano y a la vez una alianza que sería eficaz al enfrentarse a otros grupos autóctonos más hostiles. ${ }^{70}$ Así, tanto en el área mesoamericana como en la septentrional los clérigos fueron figuras fundamentales en la vida cotidiana de los indígenas. Lo mismo puede decirse de la religión católica, por más que se haya producido una forma de culto autóctona.

${ }^{69}$ Para profundizar en el culto guadalupano, véase Jacques Lafaye, Quetzalcóatl y Guadalupe, 2002, México, FCE, trad. de Ida Vitale y Fulgencio López Vidarte, pp. 285-393; y Xavier Noguez, Documentos guadalupanos, 1993, México, FCE-El Colegio Mexiquense.

${ }^{70}$ Bernd Hausberger, "La vida en el noroeste. Misiones jesuitas, pueblos y reales de minas", en Gonzalbo Aizpuru (dir.), op. cit., vol. I, pp. 443-471. 
Esto es fundamental para entender el lugar social que tenían los sacerdotes y por qué podían ayudar a apagar una rebelión, como la que ocurrió en México en 1692, por qué hubo levantamientos indígenas ante la expulsión de los padres jesuitas en 1767 o por qué en el siglo XIX los campesinos defendían no solamente la religión católica, sino su forma particular de practicarla. ${ }^{71}$

La idea original de los clérigos de mantener separada a la población fracasó pronto, y si bien muchos indígenas se mantuvieron en sus comunidades o repúblicas en relativo aislamiento de otros grupos de personas, la cercanía geográfica permitió que entraran rápidamente en contacto, lo que dio lugar a ese proceso constante de aculturación que afectó a todos los novohispanos.

\section{Conclusiones}

Tras este repaso de algunos de los aspectos más importantes de la Nueva España, queda claro que es prácticamente imposible contestar con precisión la pregunta sobre qué fue la Nueva España, puesto que uno de sus rasgos más característicos fue no ser estática, sino estar en constante transformación. Nueva España nació como una simple expectativa en la imaginación de su creador y se materializó en un reino heredero de México-Tenochtitlan y su imperio tributario, pero unido de manera accesoria a la Corona castellana y, en su momento, al Imperio de Carlos V, que se hacía presente mediante una Real Audiencia y Chancillería y después con un virrey.

Esto último volvió complejo el concepto de Nueva España, puesto que se convirtió en un virreinato que tenía jurisdicción sobre otros reinos

${ }^{71}$ Sobre las rebeliones populares (incluidas las de comunidades indígenas) por la expulsión de los miembros de la Compañía de Jesús, véase Felipe Castro, Nueva ley y nuevo rey: reformas borbónicas y rebelión popular en Nueva España, 1996, Zamora, El Colegio de Michoacán, pp. 115-173; y David A. Brading, Una Iglesia asediada: el obispado de Michoacán, 1749-1810, 1994, México, FCE, trad. de Mónica Utrilla de Neira, pp. 17-19.Para ejemplo de rebelión indígena en el siglo XIX por motivos religiosos, véase la ocurrida en el estado de Veracruz en la década de 1830, en Juan Carlos Santander Ontiveros, Entre vainillales y fusiles. Rebelión indígena en el Totonacapan, 1830-1838, 2016, México, Ediciones Navarra. 
aledaños, unos más dependientes que otros. Además, su tamaño fue variando a lo largo de los siglos XVI, XVII, XVIII y XIX, desde que se concibió solamente como una idea hasta que dejó de existir formalmente.

Nueva España tuvo además una situación geográfica estratégica como parte de la monarquía hispánica, que la hizo ser puente entre la metrópoli, las posesiones en Asia y los otros territorios americanos. A esto se debe que tuviera una población tan heterogénea en cuanto a su composición étnica y cultural. Igualmente, las desigualdades económicas entre los miembros de los distintos grupos de gente fueron considerables. Sin embargo, a todos los unía el ser vasallos de Su Majestad Católica, lo cual implicaba ser parte de la misma Iglesia.

Son todavía muchos los aspectos del periodo virreinal que desconocemos y en los que hace falta profundizar. A media que se avance en la investigación entenderemos mejor nuestro presente. Mientras tanto, no debemos olvidar que somos producto de un complejísimo proceso histórico que nos hace ser herederos de diferentes civilizaciones prehispánicas y de las ibéricas, así como también, en cierta medida, de las asiáticas y africanas. 
Se prohíbe su reproducción total o parcial por cualquier medio, incluido electrónico, sin permiso previo y por escrito de los editores. 